\title{
Structural and spectroscopic investigation of lanthanum-substituted strontium-oxybritholites
}

\author{
K BOUGHZALA $^{1}, \mathrm{~S} \mathrm{NASR}^{1}$, E BEN SALEM $^{1}, \mathrm{~F} \mathrm{KOOLI}^{2}$ and K BOUZOUITA ${ }^{1}$ * \\ ${ }^{1}$ U.R. Matériaux Inorganiques, Institut Préparatoire aux Etudes d'Ingénieurs, Rue Ibn, \\ ElJazzr, 5019 Monastir, Tunisia \\ ${ }^{2}$ Department of Chemistry, Taibah University, P.O. Box 30002, Almadinah Almunawwarah, Saudi Arabia \\ e-mail: khaled.bouzouita $@$ ipeim.rnu.tn
}

MS received 23 July 2008; revised 9 February 2009

\begin{abstract}
Lanthanum-substituted strontium-oxybritholites, $\mathrm{Sr}_{10-x} \mathrm{La}_{x}\left(\mathrm{PO}_{4}\right)_{6-x}\left(\mathrm{SiO}_{4}\right)_{x} \mathrm{O}$ with $x=0,2$ and 4 , prepared by solid state reaction were investigated by chemical analysis, powder X-ray diffraction, Raman and ${ }^{29} \mathrm{Si}$ MAS NMR spectroscopies. The refinements of powder XRD patterns of the substituted compounds by the Rietveld method showed that the lanthanum occupied the two metal sites, i.e. (4f) and (6h) sites into the apatite structure, with a clear preference for the (6h) sites. A progressive shift of the free oxygen $\mathrm{O}(4)$ towards the centre of the triangles formed by the metal-atoms in the (6h) positions was observed when the lanthanum content increased. It led to the formation of a $\mathrm{Sr} / \mathrm{La}(2)-\mathrm{O}(4)$ strong bond, which might have increased the stability of these compounds. The bands of Raman spectra were assigned to the vibration modes of $\mathrm{PO}_{4}$ and $\mathrm{SiO}_{4}$ groups. The comparison of the results of ${ }^{29} \mathrm{Si} \mathrm{MAS} \mathrm{NMR} \mathrm{analysis}$ with those obtained with the ${ }^{31} \mathrm{P}$ previously reported, suggested that both species occupied the same crystallographic sites.
\end{abstract}

Keywords. Strontium-oxybritholite; Rietveld refinement; Raman spectroscopy; ${ }^{29}$ Si MAS NMR spectroscopy.

\section{Introduction}

Apatites form a large variety of compounds with the general formula $\mathrm{M}_{10}\left(\mathrm{XO}_{4}\right)_{6} \mathrm{Y}_{2}$ where $\mathrm{M}$ represents a divalent cation $\left(\mathrm{Ca}^{2+}, \mathrm{Sr}^{2+}, \mathrm{Ba}^{2+}\right.$, etc. $), \mathrm{XO}_{4}$ a trivalent anion $\left(\mathrm{PO}_{4}^{3-}, \mathrm{VO}_{4}^{3-}\right.$, etc.) and $\mathrm{Y}$ a monovalent anion $\left(\mathrm{F}^{-}, \mathrm{Cl}^{-}, \mathrm{OH}^{-}\right.$, etc.). They crystallize mainly in the hexagonal system (space group $\mathrm{P}_{3} / \mathrm{m}$ ). ${ }^{1-3}$ A compact arrangement of $\mathrm{XO}_{4}$ tetrahedrons constitutes the skeleton of this structure which exhibits two kinds of tunnels parallel to the $c$-axis. The first is occupied by four $\mathrm{M}(1)$ cations at $4 \mathrm{f}$ sites, along a three-fold axis. These cations are coordinated by nine oxygen atoms. The second tunnel which is the larger is occupied, on its periphery, by the six other $\mathrm{M}(2)$ cations at $6 \mathrm{~h}$ sites, along a six-fold axis. These M(2) cations which are surrounded by six oxygen atoms and one $\mathrm{Y}$ atom form two alternated equilateral triangles at level $1 / 4$ and $3 / 4$ centred on a six-fold axis where the $\mathrm{Y}$ atoms are located. Various cationic, ${ }^{4-6}$ anionic, ${ }^{7,8}$ or both cationic and anionic ${ }^{9-12}$ substitutions may occur in the apatite structure. These

*For correspondence substitutions lead to substantial changes in the chemical and physical properties of the obtained materials.

Britholites, rare-earth phosphosilicates, result from the substitution of the divalent cation by a trivalent rare earth element $(\mathrm{Ln})$ and the trivalent $\mathrm{XO}_{4}$ group by the silicate tetravalent group $\left(\mathrm{SiO}_{4}\right)$. This family of compounds attracted researchers' interest because of their potential use as oxide ions conductors $^{13-15}$ or confinement matrices for the minor actinides and long-lived fission products. ${ }^{16,17}$ However, several studies have shown that the performance of these materials to store nuclear waste decreases with the increase of $\mathrm{SiO}_{4}$ groups substituting $\mathrm{PO}_{4}$ ones and the decrease of the fluorine content in the apatite framework. ${ }^{18-20}$ In agreement with this, studies focused on the thermodynamic stability of solid solutions $\mathrm{Ca}_{10-x} \mathrm{La}_{x}\left(\mathrm{PO}_{4}\right)_{6-x}\left(\mathrm{SiO}_{4}\right)_{x} \mathrm{~F}_{2}$ and $\mathrm{Ca}_{10-x} \mathrm{Nd}_{x}\left(\mathrm{PO}_{4}\right)_{6-x}\left(\mathrm{SiO}_{4}\right)_{x} \mathrm{~F}_{2}$ where $0 \leq x \leq 6$ showed that their enthalpy of formation decreased as the substitution of $\left(\mathrm{Ln}^{3+} ; \mathrm{SiO}_{4}^{4-}\right)$ for $\left(\mathrm{Ca}^{2+} ; \mathrm{PO}_{4}^{3-}\right)$ rose, ${ }^{21,22}$ while that of their analogue oxybritholites $\mathrm{Ca}_{10-x} \mathrm{La}_{x}\left(\mathrm{PO}_{4}\right)_{6-x}\left(\mathrm{SiO}_{4}\right)_{x} \mathrm{O}$ increased. ${ }^{23}$ These two series of compounds differ only according to the 
anion located on the six-fold axis of the large tunnels of the apatite structure. On the other hand, other studies showed that the distribution of lanthanide ions between both cationic sites of the apatite structure is tightly related to the nature of the anion located in these tunnels. ${ }^{24,25}$ Moreover, the substitution of silicate groups for phosphate ones has a certain influence on this distribution. ${ }^{12}$

In an attempt to find the structural modifications, an evidence for the opposite evolution of the thermodynamic stability of these two series of compounds when the silicate groups increased in the apatite structure, we decided to undertake the structural refinement of britholites using the Rietveld method in our laboratory. ${ }^{26}$ Indeed, only very few structural investigations were performed on these synthetic compounds. ${ }^{12}$ In the present work, the results of the structural refinement and spectroscopic studies of lanthanum-substituted strontium-oxybritholites, $\mathrm{Sr}_{10-x}$ $\mathrm{La}_{x}\left(\mathrm{PO}_{4}\right)_{6-x}\left(\mathrm{SiO}_{4}\right)_{x} \mathrm{O}$ with $=0,2$ and 4 are reported.

\section{Experimental}

\subsection{Synthesis}

Strontium-oxybritholites with the chemical formula of $\mathrm{Sr}_{10-x} \mathrm{La}_{x}\left(\mathrm{PO}_{4}\right)_{6-x}\left(\mathrm{SiO}_{4}\right)_{x} \mathrm{O}$ where $x=0,2$ and 4 were prepared by solid state reaction from $\mathrm{SrCO}_{3}$, $\mathrm{La}_{2} \mathrm{O}_{3}, \mathrm{SiO}_{2},\left(\mathrm{NH}_{4}\right)_{2} \mathrm{HPO}_{4}$ and $\mathrm{Sr}_{2} \mathrm{P}_{2} \mathrm{O}_{7}$.

The strontium diphosphate was prepared according to the following reaction:

$$
\begin{aligned}
& 2 \mathrm{SrCO}_{3}+2\left(\mathrm{NH}_{4}\right)_{2} \mathrm{HPO}_{4} \rightarrow \\
& \quad \mathrm{Sr}_{2} \mathrm{P}_{2} \mathrm{O}_{7}+4 \mathrm{NH}_{3}(\uparrow)+2 \mathrm{CO}_{2}(\uparrow)+3 \mathrm{H}_{2} \mathrm{O}(\uparrow) .
\end{aligned}
$$

A stoichiometric mixture of strontium carbonate and diammonium hydrogenophosphate was ground and homogenized in agate mortar, and pressed into disk. Then, it was calcined in air at $900^{\circ} \mathrm{C}$ for $10 \mathrm{~h}$.

To achieve $(\mathrm{Sr}+\mathrm{La}) /(\mathrm{P}+\mathrm{Si})$ ratios of 1.67 , appropriate reagent amounts were mixed and ground in an agate mortar. The obtained mixtures were uniaxially pressed into pellets of $30 \mathrm{~mm}$ in diameter. Then, the samples were calcined under an oxygen flow at $900^{\circ} \mathrm{C}$ for $12 \mathrm{~h}$ with a heating rate of $10^{\circ} \mathrm{C} / \mathrm{min}$. After cooling to room temperature, the pellets were ground to improve their homogeneity and then pressed again. A second heating process at a temperature ranging between 1200 and $1400^{\circ} \mathrm{C}$ for $12 \mathrm{~h}$ was performed according to the $\mathrm{SiO}_{2}$ amount. A third heating process was carried out when necessary. The synthesis reaction is:

$$
\begin{gathered}
4 \mathrm{SrCO}_{3}+(6-x) / 2 \mathrm{Sr}_{2} \mathrm{P}_{2} \mathrm{O}_{7}+x \mathrm{SiO}_{2}+x / 2 \mathrm{La}_{2} \mathrm{O}_{3} \rightarrow \\
\mathrm{Sr}_{10-x} \mathrm{La}_{x}\left(\mathrm{PO}_{4}\right)_{6-x}\left(\mathrm{SiO}_{4}\right)_{x} \mathrm{O}+4 \mathrm{CO}_{2}(\uparrow) .
\end{gathered}
$$

\subsection{Characterization}

$\mathrm{Sr}$ and La contents were determined by inductivelycoupled plasma (ICP) using a Shimadzu ICPQ/V$1014 \mathrm{~S}$ spectrometer. However, Si and P contents were estimated using atomic absorption spectroscopy (Perkin-Elmer 3110) and colorimetrically according to the Gee and Deitz method ${ }^{27}$ with a Janway 6400 spectrometer, respectively.

FTIR spectra were recorded with a Perkin Elmer 1283 spectrometer in the range of $1500-350 \mathrm{~cm}^{-1}$ using samples pressed into pellets with $\mathrm{KBr}$. Raman spectra were performed at the room temperature in the spectral range of $2000-100 \mathrm{~cm}^{-1}$ on InVia Reflex Renishaw Raman microscope equipped with deepdepleted thermoelectrically cooled CCD array detector and a high grade Leica microscope (objective $50 \times$ ). The spectra were taken using the visible $514.5 \mathrm{~nm}$ argon ion laser as the scattering excitation source

${ }^{29} \mathrm{Si}$ MAS-NMR analysis were conducted at a resonance frequency of $59.62 \mathrm{MHz}$ on a Bruker MSL300 spectrometer equipped with a cylindrical rotor of zirconium rotating at the frequency of approximately $8 \mathrm{kHz}$. The reference material for the chemical shift was the tetramethylsilane (TMS).

Powder X-ray diffraction patterns were collected with $\mathrm{CuK} \alpha$ radiation using a Philips PW 3070 diffractometer, which was equipped with a diffractedbeam graphite monochromator. The samples were scanned over the $2 \theta$ range from 10 to $110^{\circ}$ with a step size of $0.02^{\circ}$ and a counting time of $12 \mathrm{~s}$ per step. Further experimental details of data are listed in table 1. The structural refinement of the three compounds was carried out using the Rietveld method. ${ }^{28}$

\section{Results and discussion}

\subsection{Chemical analysis}

The results of the chemical analysis of the samples are reported in table 2. The contents of the different elements in the resulting products were close to those expected on the basis of the initial materials that were used. The atomic ratios $(\mathrm{Sr}+\mathrm{La}) /(\mathrm{P}+\mathrm{Si})$ were in agreement with the stoichiometric value of 1.67 for apatites. 
Table 1. Unit cell parameters and details of Rietveld refinement of $\mathrm{Sr}_{10-x} \mathrm{La}_{x}\left(\mathrm{PO}_{4}\right)_{6-x}\left(\mathrm{SiO}_{4}\right)_{x} \mathrm{O}$ samples.

\begin{tabular}{|c|c|c|c|}
\hline Formula & $\mathrm{Sr}_{10}\left(\mathrm{PO}_{4}\right)_{6} \mathrm{O}$ & $\mathrm{Sr}_{8} \mathrm{La}_{2}\left(\mathrm{PO}_{4}\right)_{4}\left(\mathrm{SiO}_{4}\right)_{2} \mathrm{O}$ & $\mathrm{Sr}_{6} \mathrm{La}_{4}\left(\mathrm{PO}_{4}\right)_{2}\left(\mathrm{SiO}_{4}\right)_{4} \mathrm{O}$ \\
\hline Formula weight & 1462.026 & $1558 \cdot 810$ & 1655.594 \\
\hline Space group symmetry & Hexagonal $P 63 / m$ & Hexagonal $P 63 / m$ & Hexagonal $P 63 / m$ \\
\hline $\begin{array}{l}\text { Formula units per cell } Z \\
\text { units cell dimensions }\end{array}$ & 1 & 1 & 1 \\
\hline$a(\AA)$ & $9.750(4)$ & $9 \cdot 756(6)$ & $9.763(6)$ \\
\hline$c(\AA)$ & $7 \cdot 278(3)$ & $7 \cdot 269(2)$ & $7 \cdot 260(2)$ \\
\hline units cell volume $V\left(\AA^{3}\right)$ & $599 \cdot 172(4)$ & $599 \cdot 168(3)$ & $599 \cdot 203(5)$ \\
\hline Density calculated $\left(\mathrm{g} \mathrm{cm}^{-3}\right)$ & $4 \cdot 051$ & $4 \cdot 319$ & $4 \cdot 588$ \\
\hline Zero point $2 \theta\left(^{\circ}\right)$ & $0 \cdot 0707(6)$ & $-0 \cdot 0384(6)$ & $-0 \cdot 0552(2)$ \\
\hline Number of parameter refined & 36 & 38 & 38 \\
\hline$R_{p}$ & $6 \cdot 64$ & 8.04 & $9 \cdot 47$ \\
\hline$R_{w p}$ & $9 \cdot 10$ & $12 \cdot 1$ & $13 \cdot 9$ \\
\hline$R_{B}$ & $4 \cdot 46$ & $4 \cdot 56$ & 5.79 \\
\hline$R_{F}$ & 3.77 & $3 \cdot 58$ & 3.77 \\
\hline
\end{tabular}

Table 2. Chemical analysis of $\mathrm{Sr}_{10-x} \mathrm{La}_{x}\left(\mathrm{PO}_{4}\right)_{6-x}\left(\mathrm{SiO}_{4}\right)_{x} \mathrm{O}$ samples.

\begin{tabular}{lccccc}
\hline Theoretical compositions & $\mathrm{Sr}$ & $\mathrm{La}$ & $\mathrm{P}$ & $\mathrm{Si}$ & $\mathrm{Sr}+\mathrm{La} / \mathrm{P}+\mathrm{Si}$ \\
\hline $\mathrm{Sr}_{10}\left(\mathrm{PO}_{4}\right)_{6} \mathrm{O}$ & 10.01 & - & 6.01 & - & 1.66 \\
$\mathrm{Sr}_{8} \mathrm{La}_{2}\left(\mathrm{PO}_{4}\right)_{4}\left(\mathrm{SiO}_{4}\right)_{2} \mathrm{O}$ & 8.01 & 1.98 & 4.00 & 2.00 & 1.66 \\
$\mathrm{Sr}_{6} \mathrm{La}_{4}\left(\mathrm{PO}_{4}\right)_{2}\left(\mathrm{SiO}_{4}\right)_{4} \mathrm{O}$ & 5.99 & 4.00 & 1.99 & 4.01 & 1.66 \\
\hline
\end{tabular}

\section{$3.2 X$-ray diffraction}

The powder X-ray diffraction patterns of the samples are shown in figure 1 . All the peaks of each pattern matched well with the JCPDS pattern 44-654 indicating that the powders were single apatite phase. The lattice parameters are given in table 1 . Those of the unsubstituted sample were in good agreement with the reported values. ${ }^{29}$ The substitution induced an increase of $\alpha$ parameter and a decrease of $c$ one, this opposite evolution was related on one hand to the size of substitutes, and on the other hand to the presence of vacancies in the channel..$^{30}$

The structural refinement was performed using the FULLPROF program. ${ }^{31}$ The previously obtained parameters ${ }^{30}$ with the atomic coordinates of $\mathrm{Sr}_{10}$ $\left(\mathrm{PO}_{4}\right)_{6} \mathrm{~F}_{2}$ were taken as preliminary data for the structural refinement of the unsubstituted compound. Then, the structural parameters of the substituted samples were refined using the data of $\mathrm{Sr}_{10}\left(\mathrm{PO}_{4}\right)_{6} \mathrm{O}$ that were determined earlier. The background determination was performed with a five order polynomial. The pseudo-Voigt function was used to fit the experimental peak profiles. The refined factors were: The scale factor, the zero shift of the diffraction, the lattice constants, the full width at half maximum, the preferred orientation, the atomic parameters, the occupancy factors and the isotropic atomic displacement parameters. The refinement of the sites occupation was carried out with a distribution of $\mathrm{La}$ atoms over the two sites with the unique constraint of the chemical composition. The occupancy factors of $\mathrm{O}, \mathrm{P} / \mathrm{Si}$ were assumed to be constant.

The final $\mathrm{R}$ factors are given in table 1 . The atomic coordinates and displacement parameters are summarized in table 3 . The observed and calculated $\mathrm{X}$-ray diffraction profiles as well as their difference are presented in figure 1 . It should be noted that when the $\mathrm{O}(4)$ was placed in the special 2 a position ( $\left.\begin{array}{lll}0 & 0 & 1 / 4\end{array}\right)$, its isotropic atomic displacement parameters were $\mathrm{B}=-1.07(3),-0.71(3)$ and $-0.064(6)$ for $\mathrm{Sr}_{10}\left(\mathrm{PO}_{4}\right)_{6} \mathrm{O}, \mathrm{Sr}_{8} \mathrm{La}_{2}\left(\mathrm{PO}_{4}\right)_{4}\left(\mathrm{SiO}_{4}\right)_{2} \mathrm{O}$ and $\mathrm{Sr}_{6} \mathrm{La}_{4}$ $\left(\mathrm{PO}_{4}\right)_{2}\left(\mathrm{SiO}_{4}\right)_{4} \mathrm{O}$, respectively. These values seem to be unreasonable. This may be due to heavier atoms or some other problems. But, when this oxygen was allowed to move along this axis, i.e. located at the 4e position $(0,0, z)$, its isotropic atomic displacement parameters were refined to more reasonable values $\mathrm{B}=0.89(3), \quad 1.65(5)$ and $1.35(5)$, respectively. However, the values of $\mathrm{R}$ factors remained unchanged. For $\mathrm{Sr}_{10}\left(\mathrm{PO}_{4}\right)_{6} \mathrm{O}, \mathrm{O}(4)$ was at the level $z=0 \cdot 326(4)$. After inserting $\mathrm{La}^{3+}$ and $\mathrm{SiO}_{4}^{4-}$ into the oxyapatite framework, the $\mathrm{O}(4)$ shifted regularly towards the centre of the triangle formed by $\mathrm{M}(2)$ - 


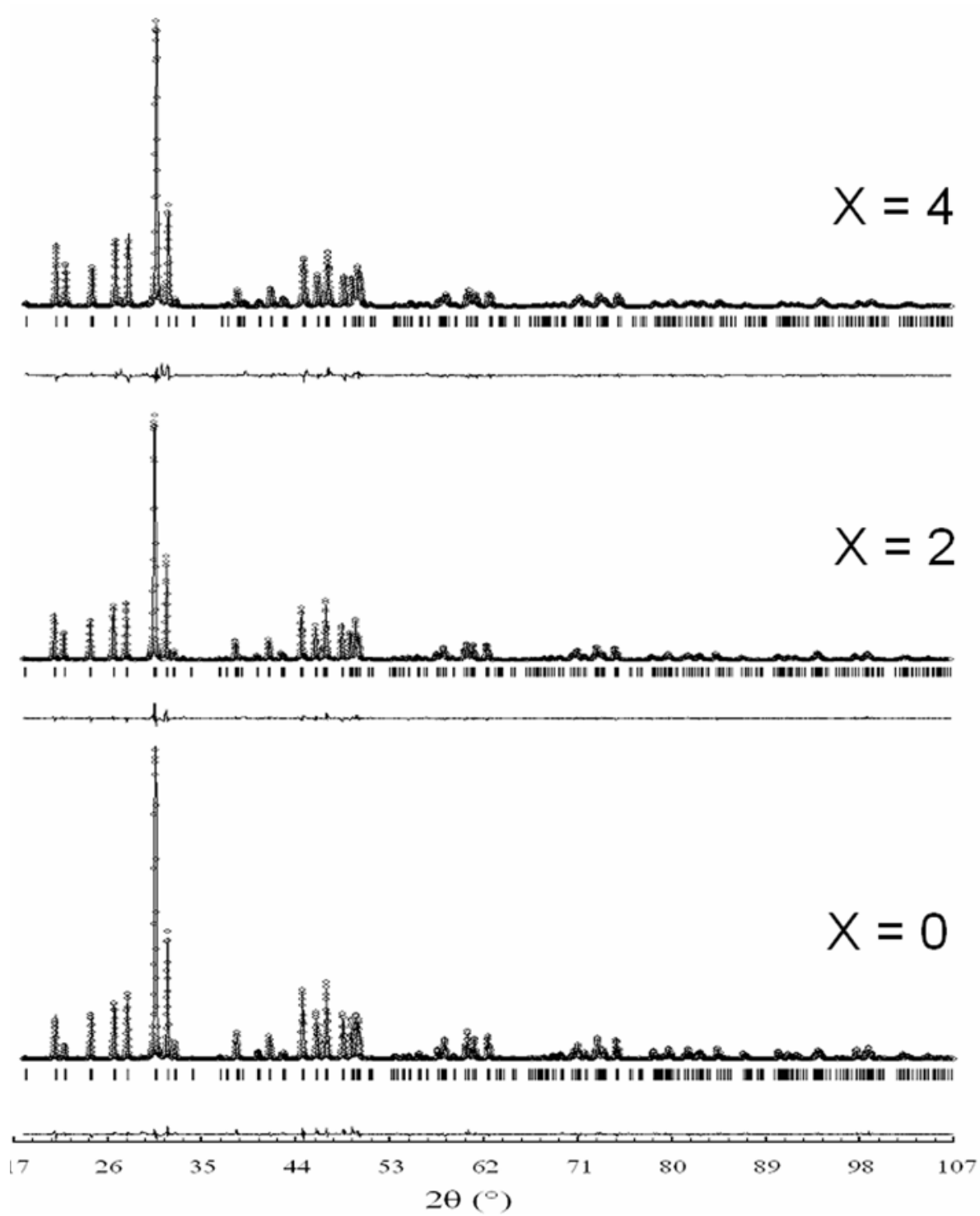

Figure 1. Experimental and calculated $\mathrm{X}$-ray diffraction patterns, and their difference of $\mathrm{Sr}_{10}\left(\mathrm{PO}_{4}\right)_{6} \mathrm{O}, \mathrm{Sr}_{8} \mathrm{La}_{2}\left(\mathrm{PO}_{4}\right)_{4}\left(\mathrm{SiO}_{4}\right)_{2} \mathrm{O}$ and $\mathrm{Sr}_{6} \mathrm{La}_{4}\left(\mathrm{PO}_{4}\right)_{2}\left(\mathrm{SiO}_{4}\right)_{4} \mathrm{O}$.

atoms $(z=1 / 4)$, at $0.323(3)$ and $0.293(7)$ for $\mathrm{Sr}_{8} \mathrm{La}_{2}\left(\mathrm{PO}_{4}\right)_{4}\left(\mathrm{SiO}_{4}\right)_{2} \mathrm{O}$ and $\mathrm{Sr}_{6} \mathrm{La}_{4}\left(\mathrm{PO}_{4}\right)_{2}\left(\mathrm{SiO}_{4}\right)_{4} \mathrm{O}$, respectively, while, for the corresponding fluorbritholites, the fluoride anion $\left(\mathrm{F}^{-}\right)$shifted in the opposite way. ${ }^{26}$ It is worth noticing that both solid solutions differ only by their monovalent anion, $\mathrm{Y}^{-}$.

Previous studies indicated that in phosphate apatites, the $\mathrm{Ln}^{3+}$ ions occupy exclusively the $(6 \mathrm{~h})$ sites, ${ }^{32,33}$ whereas when silicate groups are incorporated into the apatite structure, they are distributed over the two sites, with a marked preference for the (6 h) sites. $^{32}$ Preparing $\mathrm{Ca}-\mathrm{Nd}$-phosphosilicate, Carpena et al observed that the localization of $\mathrm{Nd}^{3+}$ ions in the cationic sites depended on operating conditions, but always with a preference for the $(6 \mathrm{~h})$ sites. $^{12}$ Preferential localization of $\mathrm{Ln}^{3+}$ ions in the $(6 \mathrm{~h})$ sites was essentially attributed to the formation of a strong bond between these cations and the anion located in the channel. ${ }^{33}$ The refinements of the sites occupation were carried out with a statistical distribution of $\mathrm{La}^{3+}$ between the two sites taking as a constraint the chemical compoition of the compounds and the fact that both sites were fully and complementarily occupied by $\mathrm{Sr}^{2+}$ and $\mathrm{La}^{3+}$ ions. The occupancy factors of $\mathrm{O}$ and $\mathrm{P} / \mathrm{Si}$ were assumed to be constant. The obtained results showed that the $\mathrm{La}^{3+}$ ions occupied preferentially the $(6 \mathrm{~h})$ sites (table 2). The rare earth element sites 
Table 3. Atomic coordinates, occupancy factors and thermal parameters after Rietveld refinement of $\mathrm{Sr}_{10-x} \mathrm{La}_{x}\left(\mathrm{PO}_{4}\right)_{6-x}$ $\left(\mathrm{SiO}_{4}\right)_{x} \mathrm{O}$ samples.

\begin{tabular}{|c|c|c|c|c|c|c|c|}
\hline Apatite & Atom & $\begin{array}{l}\text { Wyckoff } \\
\text { site }\end{array}$ & $x$ & $y$ & $z$ & $\begin{array}{c}\text { Site occu- } \\
\text { pancy factor }\end{array}$ & $\operatorname{Beq}\left[\AA^{2}\right]$ \\
\hline $\mathrm{Sr}_{10}\left(\mathrm{PO}_{4}\right)_{6} \mathrm{O}$ & $\begin{array}{l}\mathrm{Sr}(\mathrm{I}) \\
\mathrm{Sr}(\mathrm{II}) \\
\mathrm{P} \\
\mathrm{O} 1 \\
\mathrm{O} 2 \\
\mathrm{O} 3 \\
\mathrm{O} 4\end{array}$ & $\begin{array}{l}4 f \\
6 h \\
6 h \\
6 h \\
6 h \\
12 i \\
4 e\end{array}$ & $\begin{array}{l}0 \cdot 3333 \\
0 \cdot 0145(1) \\
0 \cdot 3996(3) \\
0 \cdot 3358(8) \\
0 \cdot 5813(8) \\
0 \cdot 3453(6) \\
0 \cdot 000\end{array}$ & $\begin{array}{l}0 \cdot 6667 \\
0 \cdot 2587(1) \\
0 \cdot 3660(4) \\
0 \cdot 4775(9) \\
0 \cdot 4584(8) \\
0 \cdot 2636(5) \\
0 \cdot 000\end{array}$ & $\begin{array}{l}0 \cdot 0006(3) \\
0 \cdot 250 \\
0 \cdot 250 \\
0 \cdot 250 \\
0 \cdot 250 \\
0 \cdot 075(6) \\
0 \cdot 326(4)\end{array}$ & $\begin{array}{l}1 \\
1 \\
1 \\
1 \\
1 \\
1 \\
0 \cdot 25\end{array}$ & $\begin{array}{l}1 \cdot 13(2) \\
1 \cdot 08(2) \\
1 \cdot 00(7) \\
1 \cdot 23(17) \\
0.78(16) \\
1 \cdot 52(13) \\
0 \cdot 89(3)\end{array}$ \\
\hline $\mathrm{Sr}_{8} \mathrm{La}_{2}\left(\mathrm{PO}_{4}\right)_{4}\left(\mathrm{SiO}_{4}\right)_{2} \mathrm{O}$ & $\begin{array}{l}\mathrm{Sr}(\mathrm{I}) \\
\mathrm{La}(\mathrm{I}) \\
\mathrm{Sr}(\mathrm{II}) \\
\mathrm{La}(\mathrm{II}) \\
\mathrm{P} / \mathrm{Si} \\
\mathrm{O} 1 \\
\mathrm{O} 2 \\
\mathrm{O} 3 \\
\mathrm{O} 4\end{array}$ & $\begin{array}{l}4 \mathrm{f} \\
4 \mathrm{f} \\
6 \mathrm{~h} \\
6 \mathrm{~h} \\
6 \mathrm{~h} \\
6 \mathrm{~h} \\
6 \mathrm{~h} \\
12 \mathrm{i} \\
4 \mathrm{e}\end{array}$ & $\begin{array}{l}0.333 \\
0.333 \\
0 \cdot 0133(2) \\
0 \cdot 0133(2) \\
0 \cdot 3963(5) \\
0 \cdot 3288(11) \\
0.5820(11) \\
0 \cdot 3482(7) \\
0 \cdot 000\end{array}$ & $\begin{array}{l}0.666 \\
0 \cdot 666 \\
0 \cdot 250(2) \\
0 \cdot 250(2) \\
0 \cdot 3674(5) \\
0 \cdot 4773(13) \\
0 \cdot 4603(12) \\
0 \cdot 2655(8) \\
0 \cdot 000\end{array}$ & $\begin{array}{l}0 \cdot 0013(5) \\
0 \cdot 0013(5) \\
0 \cdot 250 \\
0 \cdot 250 \\
0 \cdot 250 \\
0 \cdot 250 \\
0 \cdot 250 \\
0 \cdot 0719(8) \\
0 \cdot 3231(3)\end{array}$ & $\begin{array}{l}0 \cdot 976(2) \\
0 \cdot 024(3) \\
0 \cdot 687(3) \\
0 \cdot 313(5) \\
1 \\
1 \\
1 \\
1 \\
0 \cdot 25\end{array}$ & $\begin{array}{l}1 \cdot 26(5) \\
1 \cdot 26(5) \\
1 \cdot 55(3) \\
1 \cdot 55(3) \\
0 \cdot 94(11) \\
1 \cdot 86(3) \\
1 \cdot 17(3) \\
1 \cdot 54(2) \\
1 \cdot 65(5)\end{array}$ \\
\hline $\mathrm{Sr}_{6} \mathrm{La}_{4}\left(\mathrm{PO}_{4}\right)_{2}\left(\mathrm{SiO}_{4}\right)_{4} \mathrm{O}$ & $\begin{array}{l}\mathrm{Sr}(\mathrm{I}) \\
\mathrm{La}(\mathrm{I}) \\
\mathrm{Sr}(\mathrm{II}) \\
\mathrm{La}(\mathrm{II}) \\
\mathrm{P} / \mathrm{Si} \\
\mathrm{O} 1 \\
\mathrm{O} 2 \\
\mathrm{O} 3 \\
\mathrm{O} 4\end{array}$ & $\begin{array}{l}4 \mathrm{f} \\
4 \mathrm{f} \\
6 \mathrm{~h} \\
6 \mathrm{~h} \\
6 \mathrm{~h} \\
6 \mathrm{~h} \\
6 \mathrm{~h} \\
12 \mathrm{i} \\
4 \mathrm{e}\end{array}$ & $\begin{array}{l}0 \cdot 333 \\
0 \cdot 333 \\
0 \cdot 0136(3) \\
0 \cdot 0136(3) \\
0 \cdot 3910(7) \\
0 \cdot 3223(5) \\
0 \cdot 5938(6) \\
0 \cdot 3485(4) \\
0 \cdot 000\end{array}$ & $\begin{array}{l}0.666 \\
0.666 \\
0 \cdot 2525(2) \\
0.2525(2) \\
0 \cdot 3681(8) \\
0 \cdot 4813(7) \\
0.4713(9) \\
0 \cdot 2683(4) \\
0.000\end{array}$ & $\begin{array}{l}0 \cdot 0016(6) \\
0 \cdot 0016(6) \\
0 \cdot 250 \\
0 \cdot 250 \\
0 \cdot 250 \\
0 \cdot 250 \\
0 \cdot 250 \\
0 \cdot 0680(6) \\
0 \cdot 293(7)\end{array}$ & $\begin{array}{l}0 \cdot 739(7) \\
0 \cdot 261(4) \\
0 \cdot 508(3) \\
0 \cdot 492(5) \\
1 \\
1 \\
1 \\
1 \\
0 \cdot 25\end{array}$ & $\begin{array}{l}1 \cdot 16(6) \\
1 \cdot 16(6) \\
1 \cdot 50(4) \\
1 \cdot 50(4) \\
0 \cdot 63(8) \\
1 \cdot 68(4) \\
1 \cdot 02(2) \\
2 \cdot 58(3) \\
1 \cdot 35(5)\end{array}$ \\
\hline
\end{tabular}

occupancy ratios $[\mathrm{La}(1) / \mathrm{La}(2)]$ are 0.051 and 0.353 , respectively. For the fluorbritholites, ${ }^{26}$ these values were 0.182 and 0.355 , respectively. While in the statistical distribution, the occupancy ratio [La(1)/ $\mathrm{La}(2)]$ has a value of 0.666 . As it was observed, $\mathrm{La}^{3+}$ ions occupied preferentially the $\mathrm{M}(2)$ sites in both solid solutions. The tendency of $\mathrm{La}^{3+}$ to occupy the $\mathrm{M}(2)$ sites was greater for the smallest content, and it was even more marked for the oxybritholites. Nevertheless, regarding the values of the ratio $\mathrm{La}(1) / \mathrm{La}(2)$ for $x=4$, the shift of $\mathrm{O}(4)$ and $\mathrm{F}$ in opposite way along the six-fold axis can not be explained by a difference in the distriution of $\mathrm{La}$ over the two sites.

Selective interatomic distances and angles, together with distortion indices, are presented in table 4 . After incorporation of $\mathrm{SiO}_{4}$ into the apatite structure, the mean $\mathrm{P} / \mathrm{Si}-\mathrm{O}$ values were 1.548 and $1.598 \AA$ for $x=2$ and 4 , respectively. They are longer than the mean $\mathrm{P}-\mathrm{O}$ value $(1.530 \AA)$ in the unsubstituted compound agreeing with the $\mathrm{P}-\mathrm{O}$ distance $(1.51 \AA)$ and $\mathrm{Si}-\mathrm{O}$ one $(1.62 \AA)$ in $\mathrm{PO}_{4}$ and $\mathrm{SiO}_{4}$ tetrahedrons, ${ }^{34}$ respectively. The mean angles $\mathrm{O}-\mathrm{P} / \mathrm{Si}-\mathrm{O}$ did not vary significantly: $109 \cdot 46,109.43$ and $109 \cdot 33^{\circ}$, for $x=0,2$ and 4, respectively. However, the examination of the different angle values for the three compounds showed that the tetrahedrons were slightly deformed; the standard deviation of these angles varies from 1.64 to $4.26^{\circ}$. With the increase of $x$, the $\mathrm{Sr} / \mathrm{La}(1)-\mathrm{O}(2)$ distance slightly increased, while the other $\mathrm{Sr} / \mathrm{La}(1)-\mathrm{O}$ distances decreased significantly. Concerning the $\mathrm{Sr} / \mathrm{La}(2)-\mathrm{O}$ bond length, we noted that the $\mathrm{Sr} / \mathrm{La}(2)-\mathrm{O}(3)$ distance was longer than the $\operatorname{Sr}(2)-\mathrm{O}(3)$ one, whereas all the other $\mathrm{Sr} / \mathrm{La}(2)-\mathrm{O}$ bond lengths were smaller. Thus, after substitution, the oxygen atoms were rearranged around the $\mathrm{La}$ atom to accommodate the weak constraints due to the presence of the silicates. ${ }^{35}$ In addition, the $\mathrm{Sr} / \mathrm{La}(2)-\mathrm{O}(4)$ distance decreased. This latter decrease might be related to two concomitant effects: (i) the ionic radii difference; when larger $\mathrm{Sr}^{2+}$ ions (coord. 7: $r=1.35 \AA$ ) occupy the $(6 \mathrm{~h})$ sites, the space at the center of the triangle is reduced and the oxide ion must accommodate outside, with the incorporation of $\mathrm{La}^{3+}$ ions (coord. 7: $r_{\mathrm{La}}{ }^{3+}=1.24 \AA$ ), this space widened, and the $\mathrm{O}(4)$ 
Table 4. Selected inter atomic distances $(\AA)$, angles $\left(^{\circ}\right)$ and distortion indices for $\operatorname{Sr}_{10-x} \operatorname{La}_{x}$ $\left(\mathrm{PO}_{4}\right)_{6-x}\left(\mathrm{SiO}_{4}\right)_{x} \mathrm{O}$ compounds.

\begin{tabular}{|c|c|c|c|}
\hline & $\mathrm{Sr}_{10}\left(\mathrm{PO}_{4}\right)_{6} \mathrm{O}$ & $\mathrm{Sr}_{8} \mathrm{La}_{2}\left(\mathrm{PO}_{4}\right)_{4}\left(\mathrm{SiO}_{4}\right)_{2} \mathrm{O}$ & $\mathrm{Sr}_{6} \mathrm{La}_{4}\left(\mathrm{PO}_{4}\right)_{2}\left(\mathrm{SiO}_{4}\right)_{4} \mathrm{O}$ \\
\hline$(\mathrm{P}, \mathrm{Si})-(\mathrm{O} 1)$ & $1 \cdot 501(1)$ & $1 \cdot 513(1)$ & $1 \cdot 549(1)$ \\
\hline$(\mathrm{P}, \mathrm{Si})-(\mathrm{O} 2)$ & $1 \cdot 537(1)$ & $1 \cdot 569(2)$ & $1.710(1)$ \\
\hline$(\mathrm{P}, \mathrm{Si})-(\mathrm{O} 3)(\times 2)$ & $1 \cdot 541(1)$ & $1 \cdot 555(1)$ & $1 \cdot 568(2)$ \\
\hline$\langle(\mathrm{P}, \mathrm{Si})-\mathrm{O}\rangle$ & $1 \cdot 530$ & $1 \cdot 548$ & 1.598 \\
\hline$(\mathrm{O} 1)-(\mathrm{P}, \mathrm{Si})-(\mathrm{O} 2)$ & $110 \cdot 48(9)$ & $112 \cdot 15(9)$ & $111 \cdot 27(17)$ \\
\hline$(\mathrm{O} 1)-(\mathrm{P}, \mathrm{Si})-(\mathrm{O} 3)(\times 2)$ & $109 \cdot 73(6)$ & $110 \cdot 70(6)$ & $112 \cdot 10(12)$ \\
\hline$(\mathrm{O} 2)-(\mathrm{P}, \mathrm{Si})-(\mathrm{O} 3)(\times 2)$ & $107 \cdot 62(6)$ & $105 \cdot 16(9)$ & $102 \cdot 88(12)$ \\
\hline$(\mathrm{O} 3)-(\mathrm{P}, \mathrm{Si})-(\mathrm{O} 3)$ & $111 \cdot 59(4)$ & $112 \cdot 73(6)$ & $114 \cdot 78(10)$ \\
\hline$\langle\mathrm{O}-(\mathrm{P}, \mathrm{Si})-\mathrm{O}\rangle$ & $109 \cdot 46$ & 109.43 & $109 \cdot 33$ \\
\hline$(\mathrm{Sr} 1, \mathrm{La} 1)-\mathrm{O}(1)(\times 3)$ & $2 \cdot 600(3)$ & $2 \cdot 569(2)$ & $2 \cdot 513(1)$ \\
\hline$(\mathrm{Sr} 1, \mathrm{La} 1)-\mathrm{O}(2)(\times 3)$ & $2 \cdot 558(1)$ & $2 \cdot 564(1)$ & $2 \cdot 567(1)$ \\
\hline$(\mathrm{Sr} 1, \mathrm{La} 1)-\mathrm{O}(3)(\times 3)$ & $2 \cdot 913(2)$ & $2 \cdot 884(1)$ & $2 \cdot 878(1)$ \\
\hline$\langle(\mathrm{Sr} 1, \mathrm{La} 1)-\mathrm{O}\rangle$ & $2 \cdot 690$ & 2.672 & 2.653 \\
\hline$(\mathrm{Sr} 2, \mathrm{La} 2)-\mathrm{O}(1)$ & $2 \cdot 777(1)$ & $2 \cdot 737(2)$ & $2 \cdot 702(1)$ \\
\hline$(\mathrm{Sr} 2, \mathrm{La} 2)-\mathrm{O}(2)$ & $2 \cdot 517(1)$ & $2 \cdot 514(1)$ & $2 \cdot 444(1)$ \\
\hline$(\mathrm{Sr} 2, \mathrm{La} 2)-\mathrm{O}(3)(\times 2)$ & $2 \cdot 491(2)$ & $2 \cdot 477(2)$ & $2 \cdot 451(2)$ \\
\hline$(\mathrm{Sr} 2, \mathrm{La} 2)-\mathrm{O}(3)(\times 2)$ & $2 \cdot 702(1)$ & $2 \cdot 708(1)$ & $2 \cdot 735(3)$ \\
\hline$\langle(\mathrm{Sr} 2, \mathrm{La} 2)-\mathrm{O}\rangle$ & $2 \cdot 612$ & $2 \cdot 603$ & $2 \cdot 586$ \\
\hline$(\mathrm{Sr} 2, \mathrm{La})-\mathrm{O}(4)$ & $2 \cdot 521(4)$ & $2 \cdot 491(4)$ & $2 \cdot 416(3)$ \\
\hline $\mathrm{DI}((\mathrm{P}, \mathrm{Si})-\mathrm{O})$ & $0 \cdot 0094$ & 0.0113 & 0.0345 \\
\hline $\mathrm{DI}(\mathrm{O}-(\mathrm{P}, \mathrm{Si})-\mathrm{O})$ & $0 \cdot 0082$ & $0 \cdot 018$ & 0.0393 \\
\hline
\end{tabular}

position shifted towards the center of the triangle leading to a short $\mathrm{Sr} / \mathrm{La}(2)-\mathrm{O}(4)$ distance; (ii) the charge of $\mathrm{La}^{3+}$, which is more important than that of $\mathrm{Sr}^{2+}$. Both effects led to the formation of a strong bond, which strengthens when more La occupy these positions.

According to the works of Ardhaoui et al, ${ }^{21-23}$ the thermodynamic stability of the Ca-La-oxyabritholites increased and that of $\mathrm{Ca}-\mathrm{La}-$ fluorbritholites decreased as the substitution of $\left(\mathrm{La}^{3+} ; \mathrm{SiO}_{4}^{4-}\right)$ for $\left(\mathrm{Ca}^{2+} ; \mathrm{PO}_{4}^{3-}\right)$ rose. These authors suggested that the increase of the stability of the oxybritholites would be related to the difference between the energies of the bonds $\mathrm{Si}-\mathrm{O} \quad\left(799 \mathrm{~kJ} \mathrm{~mol}^{-1}\right)$ and $\mathrm{La}-\mathrm{O}$ $\left(799 \mathrm{~kJ} \mathrm{~mol}^{-1}\right)$, and those of $\mathrm{P}-\mathrm{O}\left(599 \mathrm{~kJ} \mathrm{~mol}^{-1}\right)$ and $\mathrm{Ca}-\mathrm{O}\left(402 \mathrm{~kJ} \mathrm{~mol}^{-1}\right) \cdot{ }^{36}$ However, this difference in the energies bonds, as they mentioned, could not explain the decrease of the stability of $\mathrm{Ca}-\mathrm{La}-$ fluorbritholites, especially, as the bond energies of $\mathrm{Ca}-\mathrm{F}$ and $\mathrm{La}-\mathrm{F}$ are $\left(527 \mathrm{~kJ} \mathrm{~mol}^{-1}\right)$ and $(598 \mathrm{~kJ}$ $\left.\mathrm{mol}^{-1}\right),{ }^{36}$ respectively. In this issue, if we assumed that the same behaviour occurred for the analog $\mathrm{Sr}-$ La-britholites, and as these two kinds of solid solutions differ only by their monovalent anion, $\mathrm{Y}^{-}$, it would seem that their difference in stability as the substitution increased would be related to the nature of this anion. As it was shown previously, for $\mathrm{Sr}-$
La-oxybritholites, the progressive shift of the free oxygen $\mathrm{O}(4)$ towards the centre of the triangles formed by the metal-atoms in the $(6 \mathrm{~h})$ positions strengthens the $\mathrm{Sr} / \mathrm{La}(2)-\mathrm{O}(4)$ bond ${ }^{33,37}$ which should confer a greater stability to the apatite structure with the increase of the substitution. However, the shift of the $\mathrm{F}^{-}$position outside the centre of the triangle should weaken $\mathrm{Sr} / \mathrm{La}(2)-\mathrm{F}$ bond explaining, consequently, the decrease in the thermodynamic stability of these compounds.

\subsection{Raman spectra}

The FT-IR spectra of the synthesized materials presented the absorption bands relative to $\mathrm{PO}_{4}$ and $\mathrm{SiO}_{4}$ groups in an apatitic environment. ${ }^{30}$

The Raman spectra of the samples are given in figure 2 . The band positions are summarized in table 5 , with assignments according to the literature. ${ }^{38-42}$ External modes corresponding to the liberational modes of $\mathrm{PO}_{4}$ and $\mathrm{SiO}_{4}$ groups, and translation ones of $\mathrm{PO}_{4}^{3-}, \mathrm{SiO}_{4}^{4}, \mathrm{Sr}^{2+}$ and $\mathrm{La}^{3+}$ ions were revealed in the frequencies range $100-300 \mathrm{~cm}^{-1}$ (figure 2a), while, the bands associated to the vibration modes of both tetrahedrons are shown in figure $2 b$. The $\mathrm{PO}_{4}$ group was revealed by the band of a significant intensity around $950 \mathrm{~cm}^{-1}$ associated to the 
Table 5. Assignments of the Raman bands for $\mathrm{Sr}_{10-x} \mathrm{La}_{x}\left(\mathrm{PO}_{4}\right)_{6-x}\left(\mathrm{SiO}_{4}\right)_{x} \mathrm{O}$ samples.

\begin{tabular}{|c|c|c|c|}
\hline $\mathrm{Sr}_{10}\left(\mathrm{PO}_{4}\right)_{6} \mathrm{O}$ & $\mathrm{Sr}_{8} \mathrm{La}_{2}\left(\mathrm{PO}_{4}\right)_{4}\left(\mathrm{SiO}_{4}\right)_{2} \mathrm{O}$ & $\mathrm{Sr}_{6} \mathrm{La}_{4}\left(\mathrm{PO}_{4}\right)_{2}\left(\mathrm{SiO}_{4}\right)_{4} \mathrm{O}$ & Assignment $\left(\mathrm{cm}^{-1}\right)$ \\
\hline 141 & 149 & - & $\mathrm{T}\left(\mathrm{PO}_{4}^{3-}\right)$ \\
\hline 169 & 169 & - & $\mathrm{R}\left(\mathrm{PO}_{4}^{3-}\right)$ \\
\hline - & - & 159 & $\mathrm{La}^{3+}$ \\
\hline 193 & 190 & 188 & $\mathrm{Sr}^{2+}$ \\
\hline - & - & 210 & $\mathrm{~T}^{\prime}\left(\mathrm{SiO}_{4}\right)$ and $\mathrm{L}\left(\mathrm{SiO}_{4}\right)$ \\
\hline 240 & 242 & - & $\left.\mathrm{Sr}^{2+}+4\right)(10)^{4}$ \\
\hline- & 277 & 266 & $\mathrm{La}-\mathrm{O}$ and $\mathrm{T}^{\prime}\left(\mathrm{SiO}_{4}\right)$ \\
\hline 951 & 949 & 952 & $v_{1}\left(\mathrm{PO}_{4}^{3-}\right)$ \\
\hline 441 & 442 & - & $v_{2}\left(\mathrm{PO}_{4}^{3-}\right)$ \\
\hline 417 & 419 & - & \\
\hline 1075 & 1075 & - & $v_{3}\left(\mathrm{PO}_{4}^{3-}\right)$ \\
\hline 1050 & 1045 & - & \\
\hline 1037 & - & - & \\
\hline 1024 & - & - & \\
\hline 997 & 999 & - & \\
\hline 621 & - & - & $\mathrm{Y}_{4}\left(\mathrm{PO}_{4}^{3-}\right)$ \\
\hline 580 & 593 & - & \\
\hline 595 & 581 & 580 & \\
\hline 572 & 574 & 573 & \\
\hline - & 846 & 846 & $v_{1}\left(\mathrm{SiO}_{4}^{4-}\right)$ \\
\hline - & 393 & 394 & $v_{2}\left(\mathrm{SiO}_{4}^{4-}\right)$ \\
\hline & 383 & 380 & \\
\hline - & 869 & 866 & $v_{3}\left(\mathrm{SiO}_{4}^{4-}\right)$ \\
\hline - & 516 & 518 & $v_{4}\left(\mathrm{SiO}_{4}^{4-}\right)$ \\
\hline - & 1218 & 1213 & Fluorescence (La) \\
\hline - & 1358 & 1354 & \\
\hline - & 1560 & 1554 & \\
\hline - & 1680 & 1678 & \\
\hline - & 1826 & 1813 & \\
\hline
\end{tabular}

symmetric stretching modes $\left(v_{1}\right)$ and the weaker bands observed at frequencies higher than $990 \mathrm{~cm}^{-1}$ attributed to the asymmetric stretching modes $\left(v_{3}\right)$. Also, the bands appearing in both ranges 450 $410 \mathrm{~cm}^{-1}$ and $630-570 \mathrm{~cm}^{-1}$ were assigned to the symmetric and asymmetric bending modes $\left(v_{2}\right.$ and $v_{4}$ ) of $\mathrm{PO}_{4}$, respectively. In addition to the bands of $\mathrm{PO}_{4}$ groups, the spectra of the substituted samples $(x=2$ and 4$)$ contained the bands associated with $\mathrm{SiO}_{4}$ groups. The bands observed around 846 and $866 \mathrm{~cm}^{-1}$ were assigned to the symmetric $\left(v_{1}\right)$ and asymmetric $\left(v_{3}\right)$ stretching modes, respectively. However, the bands relative to the symmetric bending modes $\left(v_{2}\right)$ were detected in the range of $380-400 \mathrm{~cm}^{-1}$ and the band appearing near $516 \mathrm{~cm}^{-1}$ corresponded to the asymmetric bending mode $\left(v_{4}\right)$. The bands between 1100 and $2000 \mathrm{~cm}^{-1}$ were due to the fluorescence emission of rare earth element ${ }^{43}$ (figure 2c). The increase of the $x$ value was accompanied by the decrease of the intensities of $\mathrm{PO}_{4}^{3-}$ bands and the rise of those of $\mathrm{SiO}_{4}^{4-}$.

\subsection{NMR spectroscopy}

The ${ }^{31} \mathrm{P}$ MAS NMR spectra exhibited a single resonance peak at $3.97,3.30$ and $2.19 \mathrm{ppm}$ for $\mathrm{Sr}_{10}\left(\mathrm{PO}_{4}\right)_{6} \mathrm{O}, \mathrm{Sr}_{8} \mathrm{La}_{2}\left(\mathrm{PO}_{4}\right)_{4}\left(\mathrm{SiO}_{4}\right)_{2} \mathrm{O}$ and $\mathrm{Sr}_{6} \mathrm{La}_{4}\left(\mathrm{PO}_{4}\right)_{2}$ $\left(\mathrm{SiO}_{4}\right)_{4} \mathrm{O}$, respectively, indicating only one crystallographic site for the phosphor. ${ }^{30}$ The solid ${ }^{29} \mathrm{Si}$ MAS NMR spectra of $\mathrm{Sr}_{8} \mathrm{La}_{2}\left(\mathrm{PO}_{4}\right)_{4}\left(\mathrm{SiO}_{4}\right)_{2} \mathrm{O}$ and $\mathrm{Sr}_{6} \mathrm{La}_{4}$ $\left(\mathrm{PO}_{4}\right)_{2}\left(\mathrm{SiO}_{4}\right)_{4} \mathrm{O}$ compounds are presented in figure 3 . Both spectra showed also a single resonance peak at -75.68 and $-77.68 \mathrm{ppm}$. This result related to $Q^{0}$ silicon species ${ }^{44}$ is in agreement with those obtained on apatites prepared in the $\mathrm{La}-\mathrm{Si}-\mathrm{O}$ system. ${ }^{45}$ It seems that $\mathrm{P}$ and $\mathrm{Si}$ occupied the same crystallographic site into the apatite structure.

\section{Conclusion}

Lanthanum-substituted strontium-oxyapatites with the formula of $\mathrm{Sr}_{10-x} \mathrm{La}_{x}\left(\mathrm{PO}_{4}\right)_{6-x}\left(\mathrm{SiO}_{4}\right)_{x} \mathrm{O}$ where $x=0,2$ and 4 were prepared by the solid state 

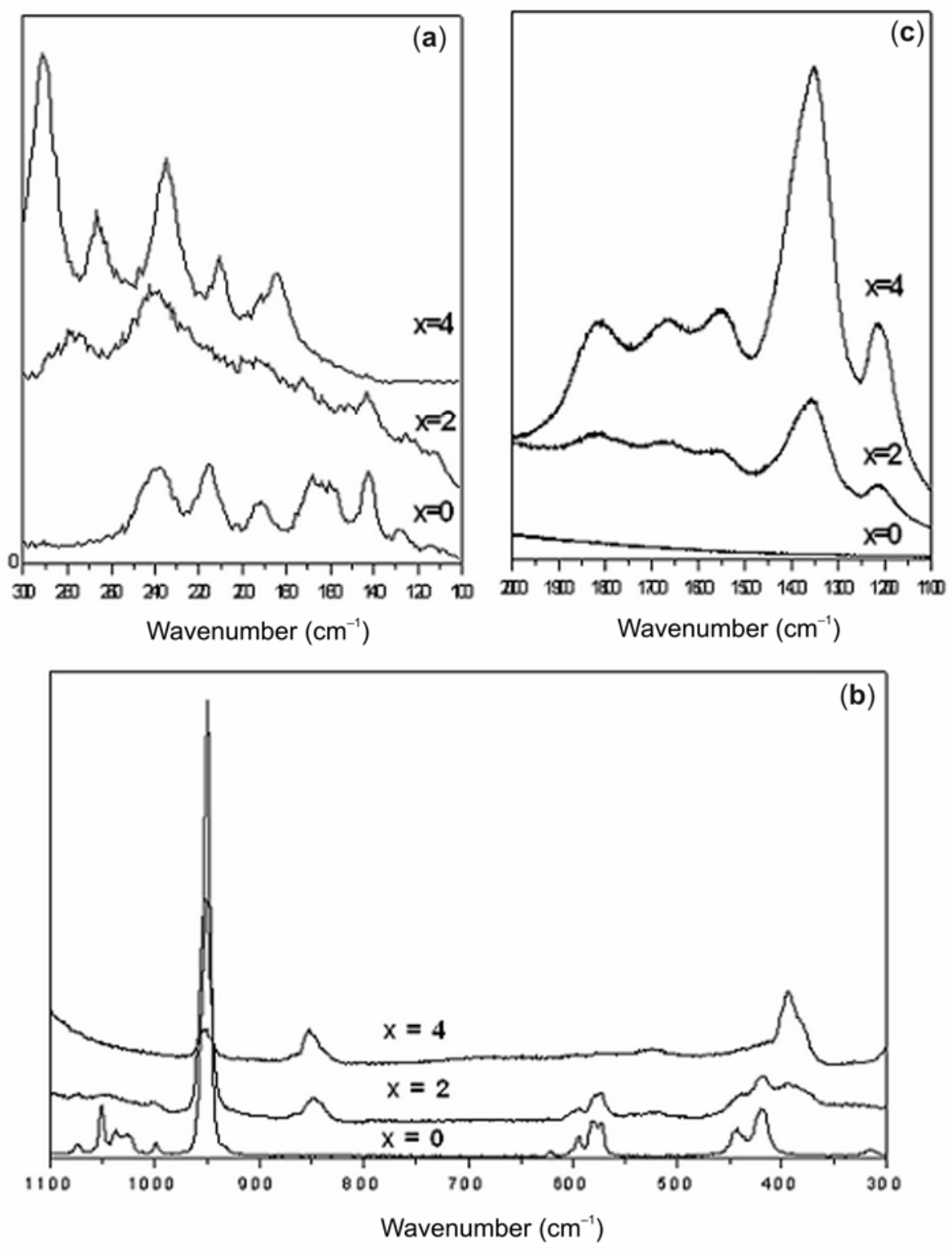

Figure 2. Raman spectra of $\mathrm{Sr}_{10-x} \mathrm{La}_{x}\left(\mathrm{PO}_{4}\right)_{6-x}\left(\mathrm{SiO}_{4}\right)_{x} \mathrm{O}$ samples: Spectral ranges were in (a) $100-300 \mathrm{~cm}^{-1}$, (b) $300-1100 \mathrm{~cm}^{-1}$ and (c) $1100-2000 \mathrm{~cm}^{-1}$.

reaction at a temperature ranging between 1200 and $1400^{\circ} \mathrm{C}$. The as-synthesized powders were characterized by X-ray diffraction, Raman spectroscopy and ${ }^{29} \mathrm{Si}$ MAS NMR. A structural investigation of these compositions was also performed using the Rietveld method. The findings showed that:

(i) The Lanthanum atoms preferentially occupied the $(6 \mathrm{~h})$ sites into the apatite structure.

(ii) When the substitution of $\left(\mathrm{La}^{3+} ; \mathrm{SiO}_{4}^{4}\right)$ for $\left(\mathrm{Ca}^{2+} ; \mathrm{PO}_{4}^{3-}\right)$ increased, a progressive shift of the $\mathrm{O}(4)$ position towards the centre of the triangle formed by the $\mathrm{M}(2)$-atoms occurred, which led to the formation of a strong bond between this oxygen and the atoms located in these sites. The formation of such a bond could contribute to a better stability of the apatite structure.

(iii) The increase of the substitution was accompanied by the decrease of the intensities of the Raman $\mathrm{PO}_{4}^{3-}$ bands and the rise of those of $\mathrm{SiO}_{4}^{4}$ ones.

(iv) The $\mathrm{Si}$ atoms occupied one crystallographic site, as indicated by ${ }^{29} \mathrm{Si}$ MAS NMR, confirming the data determined by the Rietveld investigation. 


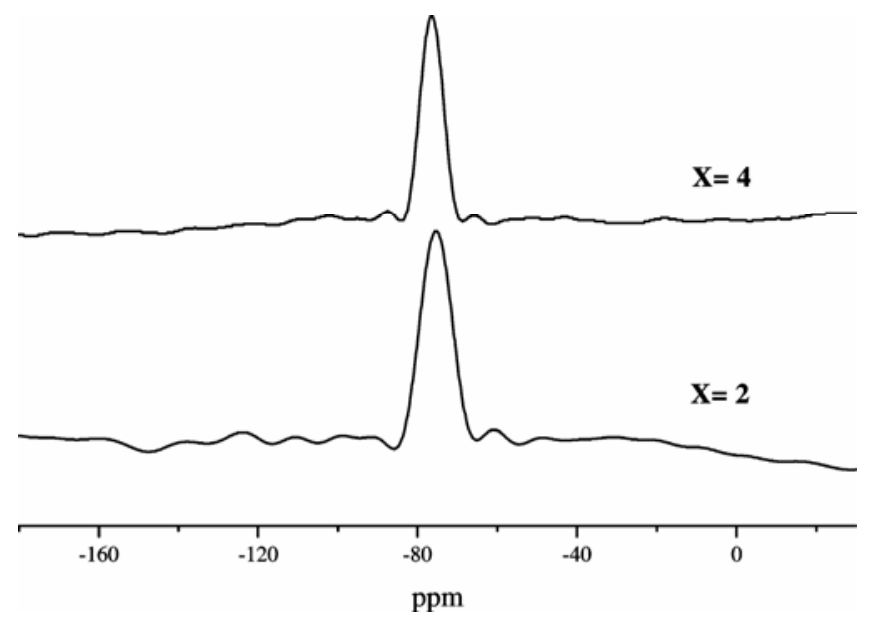

Figure 3. ${ }^{29} \mathrm{Si}$ MAS NMR spectra of $\mathrm{Sr}_{10-x} \mathrm{La}_{x}\left(\mathrm{PO}_{4}\right)_{6-x}$ $\left(\mathrm{SiO}_{4}\right)_{x} \mathrm{O}$ samples.

\section{Acknowledgment}

The authors would like to thank Mr Ridha Ben Abdlhafidh for his help in improving the manuscript with English corrections.

\section{References}

1. Elliot J C, Dykes E and Makie P E 1981 Acta Cryst. B37 435

2. Rey C 1995 l'Actual. Chim. Dec. 41

3. Sudarsanan K and Young R A 1969 Acta Cryst. B25 1534

4. Mayer I and Semadja A 1983 J. Solid State Chem. 46363

5. Aissa A, Badraoui B, Thouvenot R and Debbabi M 2004 Eur. J. Inorg. Chem. 3828

6. Badraoui B, Aissa A and Debbabi M 2007 J. Phys. Chem. Solids $\mathbf{6 8} 211$

7. Kannan S, Rebelo A and Ferreira J M F 2006 J. Inorg. Biochem. 1001692

8. Ślósarczyk A, Paszkiewicz Z and Paluszkiewicz C 2005 J. Mol. Struct. 744657

9. El Feki H, Savariault J M, Ben Salah A and Jemal M 2000 Solid State Sci. 2577

10. Sprio S, Tampieri A, Landi E, Sandri M, Martorana S, Celotti G and Logroscino G 2008 Mater. Sci. Eng. C28 179

11. Boyer L, Carpéna J and Lacout J L 1997 Solid State Ionics 95121

12. Carpena J, Boyer L, Fialin M, Kienast J R and Lacout J L 2001 C. R. Acad. Sci. Paris 333373

13. Nakayama S, Aono H and Sadaoka Y 1995 Chem. Lett. 24431

14. Slater P R, Sansom J E H and Tolchard J R 2004 Chem. Rec. 4373

15. Sansom J E H, Richings D and Slater P R 2001 Solid State Ionics 139205

16. Bros R, Carpena J, Sere V and Beltritti A 1996 Radiochim. Acta 74277
17. Carpena J, Kienast J R, Ouzegane $\mathrm{K}$ and Jehanno $\mathrm{C}$ 1988 Geol. Soc. Am. Bull. 1001237

18. Carpena J 1998 in Advances in fission track geochronology (eds) P Van den Haute and de Corte (Dordrecht: Kluwer Academic Publishers) p. 91

19. Carpena J, Boyer L and Lacout J L 1998 French Patent 9811334

20. Meis C, Gale J D, Boyer L, Carpena J and Grosset J 2000 J. Phys. Chem. A104 5380

21. Ardhaoui K, Coulet M V, Ben Chérifa A, Carpena J, Rogez J and Jemal M 2006 Thermochim. Acta 444 190

22. Ardhaoui K 2006 Synthèse, caractérisation et détermination des grandeurs thermochimiques de britholites à base de lanthane et néodyme Doctoral Thesis University of Tunis Tunisia

23. Ardhaoui K, Rogez J, Ben Chérifa A, Rogez J, Jemal $\mathrm{M}$ and Satre P 2006 J. Therm. Anal. Calorim. 86553

24. Fleet M E, Liu X and Pan Y 2000 Am. Mineral. 85 1437

25. Fleet M E and Pan Y 1994 J. Solid State Chem. 111 78

26. Boughzala K, Ben Salem E, Kooli F, Gravereau P and Bouzouita K 2008 J. Rare Earth 26483

27. Gee A and Deitz V R 1953 Anal. Chem. 251320

28. Rietveld H M 1969 J. Appl. Cryst. 265

29. JCPDS File no. 44-654

30. Boughzala K, Ben Salem E, Ben Chrifa A, Gaudin E and Bouzouita K 2007 Mater. Res. Bull. 421221

31. Rodriguez-Carvajal 1990 In Collected abstract of powder diffraction meeting, vol. 127 Toulouse France

32. Fleet M E, Liu X and Pan Y 2000 J. Solid. State Chem. 149391

33. Schroeder L W and Mathew M 1978 J. Solid State Chem. 26383

34. Shannon R D 1976 Acta Cryst. A32 751

35. Louis-Achille V 1999 Atomistic modelling study of lanthanides incorporation in the crystal lattice of an apatite Doctoral Thesis University of Paris VI France

36. Lide D R 2004 Handbook of chemistry and physics 85 Boca Raton (Fla.), London, New York: CRC Press 52

37. Piriou B, Fahini D, Dexpert-Ghys J, Taitai A and Lacout J L 1987 J. Lumin. 3997

38. Rodriguez-Reyna E, Fuentes A F, Maczka M, Hanuza J, Boulahya K and Amador U 2006 J. Solid State Chem. 179522

39. Benarafa L, Rghioui L, Nejjar R, Saidi Idrissi M, Knidriri M, Lorraux A and Wallart F 2005 Spectrochim. Acta A61 419

40. Khorari S, Cahay R, Rulmont A and Tarte P 1994 Eur. J. Solid State Inorg. Chem. 31921

41. Fowler B O 1974 Inorg. Chem. 13194

42. Neubauer J and Pollmann H 1995 Neues. Jahrb. Mineral. Abh. 168237

43. Aminzadeh A 1997 Acta A49 693

44. Engelhardt G and Michel D 1987 High resolution solid-state NMR of silicates and zeolites (Norwich: John Wiley)

45. Sansom J E H, Tolchard J R, Islam M S, Apperley D and Slater P R 2006 J. Mater. Chem. 161410 